\title{
МЕТОДИЧНІ ПІДХОДИ ДО ВИЗНАЧЕННЯ РОЗМІРУ ОХОРОННОЇ ДІЛЯНКИ НАВКОЛО ГНІЗДА ЛЕЛЕКИ ЧОРНОГО CICONIA NIGRA (L.)
}

Наприкінці 2016 р. у законодавче поле України введено поняття охоронної ділянки навколо гнізд рідкісних видів птахів, зокрема занесеного до Червоної книги України (2009) лелеки чорного Ciconia nigra (L.). Радіус ділянки для усіх видів визначено за європейськими стандартами, однак для лелеки він збільшений удвічі, до радіуса 1000 м навколо гнізда впродовж усього року. У 2006-2018 pр. проведено дослідження чисельності, поширення, біотопних преференцій та гніздової біології виду на території Українського Полісся (Волинська, Рівненська, Житомирська, Київська, Чернігівська та Сумська області) та подальший моніторинг гніздової біології чорного лелеки на Західному Поліссі (Волинська та Рівненська області). Дослідженнями доведено, що радіус 1000 м навколо гнізда $є$ надмірним і недоцільним. Першою хибою такого підходу є відсутність врахування сезонності під час створення охоронної ділянки, другою - надмірний радіус. Обгрунтовано оптимальні розміри охоронної ділянки навколо гнізда лелеки чорного. Доведено, що 54 \% гнізд розташовані не далі ніж 200 м від краю лісу. Важливість для виду 500-метрової ділянки лісу навколо гнізда підтверджують і білоруські науковці. За їхніми даними, у 83,3 \% випадків на цій території знаходиться присід чорного лелеки, який птахи використовують для оцінювання безпеки підльоту до гнізда. Враховуючи сезонність, рекомендовано створювати охоронні ділянки з двох частин - ділянки суворої охорони (радіусом не менше 100 м довкола гнізда) та ділянки сезонної охорони (радіусом не менше 500 м). Ділянка суворої охорони діє впродовж усього року і в ній заборонено будь-яку діяльність, навіть перебування людей. На ділянці сезонної охорони заборонено будь-яку діяльність 315 березня по 30 липня. На лісових дорогах і просіках, що проходять через ділянку суворої охорони, рекомендуємо встановлювати попереджувальні аншлаги. Роботи здійснено в рамках проекту "СiconiaUkraina", який реалізується Західноукраїнським орнітологічним товариством та Державним природознавчим музеєм НАН України, за фінансової підтримки Фонду "Сiconia" (Ліхтенштейн).

Ключові слова: лелека чорний; гніздова територія; охоронні ділянки; охорона.

Вступ. Збереження біологічного різноманіття в умовах ведення лісового господарства в нашій країні сьогодні $є$ однією з найважливіших і найскладніших проблем. Останнім часом, завдяки активізації громадських природоохоронних організацій, Міністерство екології та природних ресурсів України і Державне агентство лісових ресурсів України наблизили наше законодавство до європейського, ввівши поняття охоронних ділянок навколо гнізд рідкісних видів птахів, зокрема і занесеного до Червоної книги України (2009) лелеки чорного Ciconia nigra (L., 1758). Ці зміни втілено у нових Санітарних правилах у лісах України (Sanitarni pravyla, 2016), затверджених постановою Кабінету Мiністрів України від 27.07.1995 № 555 (в редакції постанови Кабінету Міністрів України від 26.10.2016 № 756) (Postanova Kabinetu, 2016) та Наказі Міністерства екології природних ресурсів України від 29.12.2016 № 557 "Про додаткові заходи щодо збереження рідкісних та зникаючих видів тварин і рослин" (Nakaz Ministerstva, 2016). Призначення охоронної ділянки - запобігти турбуванню птахів, особливо в гніздовий період, і зберегти їхнє оселище.

Проте замість того, щоб скористатися міжнародним досвідом визначення розмірів охоронних ділянок навколо гнізд чорного лелеки і досвідом українських науковців, які досліджують цей вид, в обох документах визначено цілком безпідставні розміри охоронної ділянки. Зокрема, в Санітарних правилах у лісах України зазначено: "Забороняється проведення санітарно-оздоровчих заходів навколо місця гніздування ... чорного лелеки (радіусом 1000 м)". У Наказі Мінприроди № 557 визначено такий самий радіус охоронної ділянки впродовж усього року.

Першою хибою такого підходу $є$ відсутність сезонності у визначенні розмірів охоронної ділянки, другою - надмірний радіус.

Цілком зрозуміло, що з природоохоронного погляду, чим більший радіус охоронної ділянки, тим краще для птахів. Однак необхідно знайти оптимальне вирішення цього питання, як це відбувається в цивілізованих країнах. В Україні понад 88 \% популяції з близько 1000 пар лелеки чорного гніздиться в господарських ліcax i лише $12 \%$ - в об'єктах природно-заповідного фонду. Отже, для збереження виду потрібно знайти оптимальне рішення, за якого буде забезпечена максимальна охорона гніздових ділянок лелеки чорного і водночас

\section{Інформація про авторів:}

Бокотей Андрій Андрійович, канд. біол. наук, ст. наук. співробітник, докторант, кафедра лісівництва.

Email: bokotey.a@gmail.com

Цитування за ДстУ: Бокотей А. А. Методичні підходи до визначення розміру охоронної ділянки навколо гнізда лелеки чорного Ciconia Nigra (L.). Науковий вісник НЛТУ України. 2019, т. 29, № 2. С. 31-34.

Citation APA: Bokotey, A. A. (2019). An approach to determine the size of the protected zone around the Black Stork Ciconia Nigra (L.) nests. Scientific Bulletin of UNFU, 29(2), 31-34. https://doi.org/10.15421/40290206 
працівники лісового господарства зможуть виконувати свої планові завдання.

Мета нашої роботи - обгрунтувати оптимальні розміри охоронної ділянки навколо гнізда лелеки чорного.

Матеріали та методи дослідження. Матеріал зібрано впродовж 2006-2009 рр. під час інвентаризації гнізд чорного лелеки в Українському Поліссі (Волинська, Рівненська, Житомирська, Київська, Чернігівська та Сумська області) та подальших моніторингових досліджень гніздової біології чорного лелеки на Західному Поліссі (Волинська та Рівненська області) у 20102018 pp. (рис. 1). Роботи здійснено в рамках проекту "Ciconia-Ukraina", який реалізується Західноукраїнським орнітологічним товариством та Державним природознавчим музеєм НАН України, за фінансової підтримки Фонду "Ciconia" (Ліхтенштейн).

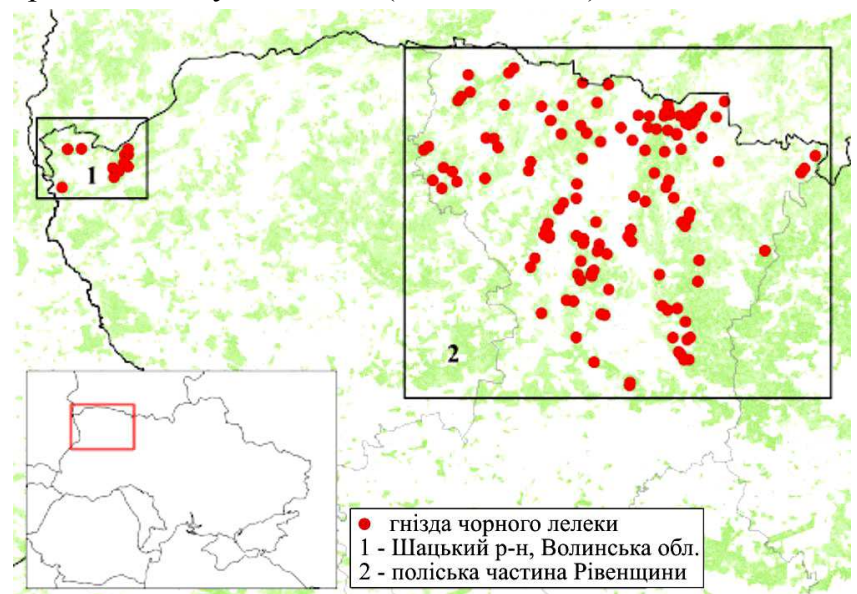

Рис. 1. Територія моніторингових досліджень лелеки чорного в Україні в 2010-2018 pp.

Збір матеріалу проводили шляхом анкетування працівників держлісгоспів, мисливських господарств, об'єктів природно-заповідного фонду та місцевого населення. У всіх випадках інформацію про гніздо перевіряли шляхом його відвідування у негніздовий період (вересень - березень) або в другій половині червня (для кільцювання пташенят). Виявлені гнізда та гніздові території детально описували та картували за допомогою приладів GPS. В окремих випадках проводили самостійний пошук гнізд, шляхом детального обстеження потенційно придатних для гніздування лелеки ділянок лісу.

Для аналізу картографічного матеріалу застосовано оверлейний аналіз в ГІС. Для аналізу використано точні локалізації 108 гнізд чорного лелеки та шари, що містять інформацію про типи лісу, панівні лісові породи, лісорослинні умови, вік лісу та бонітет. Для оцінювання впливу рубок лісу, як фрагментуючого фактора, використано дані Global Forest Watch у перетині з круговими буферами навколо 141 гнізда чорних лелек. Аналіз структури біотопу проводили на обмежених за площею територіях навколо гнізд, а саме в кругових буферах діаметром від 0 до 500 м навколо гнізд, із кроком в 100 м. Детальніше методику вирахування площ біотопів та масштабів рубок описано в нашій попередній статті (Bokotey et al., 2017).

Відстані від гнізд до найближчого краю лісу вимірювали за допомогою програми QGIS 2.8.16, на основі геоприв'язаних знімків надвисокої роздільної здатності зі сервісів Google Maps та Bing Maps (завантажених через OpenLayers plugin). Усі виміри здійснювали у проекції знімків - WGS84/Pseudo Mercator (EPSG: 3857).
Результати та обговорення. Результати наших досліджень в Українському Поліссі показують, що існує залежність між загальною структурою лісового покриву в регіоні і поширенням чорного лелеки. Лелека заселяє найпоширеніші типи лісу. Більшої переваги надає гніздуванню у вологих дубово-соснових суборах (на $8 \%$ частіше) порівняно з іншими лісами. Рідше обирає для гніздування свіжі дубово-соснові субори та свіжі соснові бори (на 8 і 5 \% відповідно).

Стосовно вікового складу лісів чорний лелека надає перевагу лісостанам старіших класів віку. Пристигаючим лісам надає перевагу на $20 \%$ частіше, ніж іншим, а стиглим - майже на $18 \%$. Загалом найпридатнішим біотопом для поселення виду є ліси старших категорій. Зазвичай у цих лісах проводять інтенсивні лісогосподарські заходи, зокрема прохідні, санітарні, лісовідновні рубки, рубки головного користування.

Рубки виявлено на 37,3 \% гніздових ділянок у межах 100-метрової буферної зони навколо гнізд. На понад $14 \%$ ділянок (у 100-метрових буферах) втрата лісового покриву перевищує $20 \%$ від загальної площі лісу в них. 3 результатів випливає, що рубання лісів є однією з основних загроз для локальної гніздової популяції в регіоні та основним фактором фрагментації середовища гніздування чорного лелеки (Strus et al., 2017).

Наведені вище результати досліджень свідчать про своєчасність і доцільність законодавчого захисту гнізд чорного лелеки й інших рідкісних видів птахів у лісах, шляхом створення охоронних ділянок навколо них.

Гніздо лелеки -це велика масивна конструкція, яку може витримати тільки добре розвинене потужне дерево. Також дерево повинно мати і відповідну конфігурацію крони, аби лелека міг збудувати гніздо. Окрім цього, лелека, як птах з великим розмахом крил, не має змоги маневрувати в густому лісі і гніздо будує недалеко від узлісся або просіки, на товстих бічних гілках або в розвилці стовбура. Однак навіть у лісах старшого віку важко знайти дерева, що відповідали б усім цим вимогам (Lõhmus \& Sellis, 2003).

У виборі місця гніздування лелека зважає на кілька основних факторів: наявність старших деревостанів, близькість кормових територій, розташування гнізда 3 огляду на території інших особин свого виду, а також фактора турбування.

Ще однією дуже важливою особливістю гніздової поведінки чорного лелеки є те, що він підлітає до гнізда ховаючись у лісі, а не опускаючись на нього з висоти. Це зумовлене необхідністю захисту потомства від хижих птахів. Отже, гнізда ніколи не розташовуються на узліссі, проте й виключно рідко в глибині лісу. Для визначення оптимальної відстані розміщення гнізда до найближчого відкритого простору (вирубки, лісової галявини чи іншого типу відкритих ділянок) виміряли іiі для 147 гнізд (рис. 2).

Як видно 3 рис. 2, чорний лелека обирає місця для гніздування неподалік від узлісся. 54 \% гнізд розташовані не далі ніж 200 м від краю лісу, а $27 \%$ - не далі 100 м. Ця невелика ділянка лісу між гніздом і узліссям потрібна птахові, щоб непоміченим пролетіти між деревами до гнізда. Чим довший цей маршрут, тим важче птахові його долати маневруючи між деревами і тим більше енергії він затрачатиме підлітаючи до гнізда, особливо в період вигодовування пташенят. 


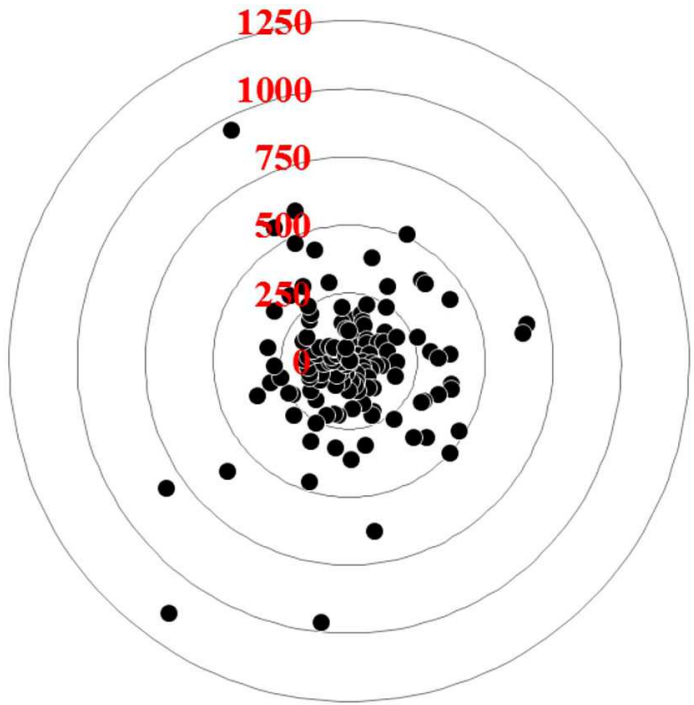

Рис. 2. Розподіл гнізд лелеки чорного на Західному Поліссі за відстанню до найближчого відкритого простору (узлісь, вирубок, галявин та ін.)

Невелика відстань від відкритого простору до гнізда потрібна птахові ще з такої причини. Перед підльотом до гнізда птах спочатку сідає на присід недалеко від гнізда, щоб впевнитися у відсутності небезпеки і лише потім летить лісом до гнізда. Дослідження білоруських орнітологів показали, що такий присід чорний лелека у 83,3 \% випадків знаходить на відстані до 500 м від гнізда (Dmitrenok et al., 2012).

Отже, 3 викладеного цілком очевидно, що немає жодних підстав для радіуса охоронної ділянки навколо гнізда чорного лелеки у 1000 м. Лелека - птах рибоїдний і харчується на річках і стоячих водоймах за межами лісу, найчастіше на віддалі 5-10 км, а іноді й більше від свого гнізда (Strazds, 2011). Тому нам важко зрозуміти мотивацію авторів закону, які цілком безпідставно визначили охоронну ділянку навколо гнізда лелеки чорного, радіусом 1000 м.

Базуючись на міжнародному досвіді і власних дослідженнях (таблиця), вважаємо, що для охоронної ділянки навколо гнізда чорного лелеки необхідно враховувати сезонність. Це дасть змогу працівникам лісового господарства у позагніздовий період, без заподіяння шкоди лелекам, проводити необхідну господарську діяльність.

Таблиця. Розміри охоронних ділянок навколо гнізд лелеки чорного у різних свропейських країнах

\begin{tabular}{|c|c|c|c|}
\hline \multirow{2}{*}{ Країна } & Охоронна ділянка & \multirow{2}{*}{ Автор } \\
\cline { 2 - 3 } & Сувора & Сезонна & \\
\hline Угорщина & 100 & 400 & Kalocsa, Tamas, 2006 \\
\hline Польща & 200 & 500 & Marchowski, 2015 \\
\hline Німеччина & 100 & 500 & Ryslavy, Putze, 2000 \\
\hline Чехія & 200 & - & Pojer, Vojtechovska, 2012 \\
\hline Латвія & 250 & - & Strazds, 2011 \\
\hline Білорусь & 250 & & Красная книга..., 2004 \\
\hline \multirow{2}{*}{ Україна } & 1000 & - & Санітарні правила ..., 2016 \\
\cline { 2 - 3 } & 100 & 500 & Рекомендована нами \\
\hline
\end{tabular}

Охоронна ділянка повинна складатися 3 двох частин - ділянки суворої охорони та ділянки сезонної охорони. Для чорного лелеки ділянка суворої хорони має включати територію радіусом не менше 100 м довкола гнізда. На цій території рекомендується заборонити здійснення будь-якої діяльності та робіт впродовж усього року, а під час гніздового періоду - навіть перебування людей. В умовах лісової зони України гніздо- вий період лелеки чорного триває від 15 березня до 30 липня.

На лісових дорогах і просіках, що проходять через зону суворої охорони, мають стояти попереджувальні аншлаги такого змісту - "Увага! Місце розмноження тварин, занесених до Червоної книги України. Вхід заборонено з 15 березня до 30 липня. В інший період року просимо не порушувати їхніх оселищ". Окрім цього, у зоні сезонної охорони під час гніздового періоду рекомендується заборонити проведення будь-якої діяльності та робіт на території радіусом не менше 500 м навколо гнізда.

Висновки. 3 перелічених вище фактів цілком очевидно, що в сучасних сильно фрагментованих лісостанах ділянка навколо гнізда радіусом 1000 м не стільки сприяє охороні лелеки чорного, скільки призводить до конфліктних ситуацій між природоохоронцями і працівниками лісового господарства.

Охоронна ділянка повинна бути сезонною і складатися $з$ двох частин - ділянки суворої охорони (радіусом не менше 100 м довкола гнізда) та ділянки сезонної охорони (радіусом не менше 500 м). Ділянка суворої охорони діє впродовж усього року і в ній заборонено будь-яку діяльність, навіть перебування людей. На ділянці сезонної охорони заборонено будь-яку діяльність з 15 березня по 30 липня.

На лісових дорогах і просіках, що проходять через зону суворої охорони, рекомендуємо встановлювати попереджувальні аншлаги.

Подяки. Автор висловлює щиру вдячність своєму колезі Юрію Струсу за допомогу у зборі та опрацюванні матеріалу.

\section{Перелік використаних джерел}

Bokotey, A., Strus, Iu., \& Dzubenko, N. (2017). Nesting habitats of Black Stork (Ciconia nigra L.) in Ukrainian forest zone (Polissia) revealed by an overlay analysis in GIS. Proceedings of the State Natural History Museum, 33, 75-80.

Dmitrenok, M., Dombrovski, V., \& Pakul, P. (2012). A methods of estimating numbers and searching for Black Stork's nests: results of a study in Belarus. Ornithos, 1, 142-147.

Kalocsa, B., \& Tamas, E. A. (2002). Data on the diet of Black Stork (Ciconia nigra) in Hungary as based on field investigations between 1996-2000. Aquila, 107-108, 241-247.

Kalocsa, B., \& Tamas, E. A. (2006). Analysis of the nesting data of Black Storks Ciconia nigra in the Gemenc region of the DanubeDrava National Park (1992-2003). Biota, 7(1-2), 47-56.

Krasnaja kniga. (2004). Red Data Book of Belorussian Republic. Animals. Minsk: Belarusskaja jenciklopedija. [In Russian].

Lõhmus, A., \& Sellis, U. (2003). Nest trees - a limiting factor for the Black Stork (Ciconia nigra) population in Estonia. Aves, 40(1-4), 84-91.

Marchowski, D. (2015). Ptaki Polski. Kompletna lista 450 stwierdzonych gatunkow. Warszawa.

On Additional. (2016). Order of the Ministry of Ecology and Natural Resources of Ukraine "On Additional Measures for the Conservation of Rare and Endangered Species of Animals and Plants" of December 29, No. 557. Retrieved from: http://old.menr.gov.ua/docs/ normakty/2016/nakaz 557 29122016.pdf. [In Ukrainian].

On Amendments. (2016). Resolution of the Cabinet of Ministers of Ukraine "On Amendments to Resolutions of the Cabinet of Ministers of Ukraine No. 555 of July 27, 1995 and No. 724 of May 12, 2007", October 26, No. 756. Retrieved from: http://zakon2. wrada.gov.ua/laws/show/756-2016-\%D0\%BF. [In Ukrainian].

Pojer, F., \& Vojtechovska, E. (2012). La Cigogne noire en République Tchèque: état de la population et conservation. Ornithos, 1, 36-37. 
Red Data. (2009). Red Data Book of Ukraine. Animals. Kyiv: Globalkonsalting. Retrieved from: http://redbook-ua.org/files/ Red book_animals 2009.zip. [In Ukrainian].

Ryslavy, T, \& Putze, M. (2000). Zum Schwarzstorch (Ciconia nigra [L., 1758]) in Brandenburg. Naturschutz und Landschaftspflege in Brandenburg, 9(3), 88-96.

Sanitary rules. (2016). Sanitary rules in the forests of Ukraine (as amended by the Resolution of the Cabinet of Ministers of Ukraine of October 26, 2016, No. 756). Retrieved from: http://zakon2.rada. gov.ua/laws/show/555-95-\%D0\%BF. [In Ukrainian].

Strazds, M. (2011). Conservation Ecology of the Black Stork in Latvia. $\mathrm{PhD}$ thesis. Riga.

Strus, Iu., Bokotey, A., \& Dzubenko, N. (2017). Detection of forest loss on Black Stork breeding sites in the Rivne region (Polissia) by a GIS analysis. Proceedings of the State Natural History Museum, $33,75-80$

A. A. Bokotey

Ukrainian National Forestry University, Lviv, Ukraine

\section{AN APPROACH TO DETERMINE THE SIZE OF THE PROTECTED ZONE AROUND THE BLACK STORK CICONIA NIGRA (L.) NESTS}

At the end of 2016, the concept of protection zones around nests of rare species of birds was introduced into Ukrainian legislation. This applies to the Black Stork Ciconia nigra (L.), a species listed in the Red Data Book of Ukraine (2009). For all species except Storks the radius of a protection zone is equal to European standards, but for this particular species, it was increased to the radius of $1000 \mathrm{~m}$ around the nest throughout the whole year. In 2006-2018 studies of the number and distribution, biotope preferences and nesting biology of the species on the territory of the Ukrainian Polissya (Volyn, Rivne, Zhytomyr, Kiev, Chernihiv and Sumy regions) were conducted. On the Western Polissya (Volyn and Rivne area) permanent monitoring of the nesting biology of Black Stork was done. The studies have shown that the radius of $1000 \mathrm{~m}$ around the nest is excessive and inappropriate. The first drawback of such an approach is the lack of seasonality when creating a protection zone. The second one is such a large radius. The aim of this paper is to provide arguments supporting an optimal size of protection zones around Black Stork nests. It was proven that $54 \%$ of nests are located not farther than $200 \mathrm{~m}$ from the edge of the forest. The importance of the 500-meter forest area around the nest is also confirmed by Belarusian scientists. According to their data, in $83.3 \%$ of cases, the perching place of Black Storks is located within this distance and is needed for birds to estimate the safety of approaching a nest. It is recommended to consider seasonality and to create protection zones of two types - zones of strict protection (with a radius of at least $100 \mathrm{~m}$ around the nest) and zones of seasonal protection (radius of not less than $500 \mathrm{~m}$ ). Within zones of strict protection, any human activity and even presence of people should be forbidden throughout the year. In areas of seasonal protection, the same should be implied only in a period between March 15 and July 30. On forest roads and clearings that pass through the area of strict protection, we recommend the installation of special signs. The study was financially supported by the "CICONIA" fund (Lichtenstein) within the scope of the project "Ciconia-Ukraina" that was realized by West-Ukrainian Ornithological Society and State Museum of Natural History of NAS of Ukraine.

Keywords: Black Stork; nesting territory; protection zones; conservation. 